\title{
Fatty Acid Biosynthesis in Human Erythrocytes: Evidence in Mature Erythrocytes for an Incomplete Long Chain Fatty Acid Synthesizing System*
}

\author{
Joseph G. Pitrman † and Donald B. Martin \\ (From the Department of Medicine, Harvard Medical School, and the Medical Services, \\ Endocrine Unit, Massachusetts General Hospital, Boston, Mass.)
}

The synthesis of long chain fatty acids from acetate in mammalian, extramitochondrial ("soluble") systems requires three enzymatic steps: 1 ) the activation of acetate to form acetyl-coenzyme A (acetyl-CoA), 2) the carboxylation of acetylCoA by the enzyme acetyl-CoA carboxylase to form malonyl-coenzyme A (malonyl-CoA), and 3 ) the subsequent complex series of serial condensations of malonyl-CoA to the elongating acyl-CoA compound [the intermediates may be bound to acyl carrier protein rather than $\operatorname{CoA}(1)]$ by the enzyme palmitate synthetase to form the resultant long chain fatty acid, shown in Table I.

The synthesis of long chain fatty acids from acetyl-CoA has been studied extensively in enzyme systems from a number of sources, including rat, beef, and human adipose tissue (2-4), avian and mammalian liver (5-7), rat lactating mammary gland $(8,9)$, rat brain $(10)$, yeast (11), plants (12), insects $(13,14)$, and bacteria (15). The formation of acetyl-CoA from acetate, although less extensively studied as an initial step in fatty acid biosynthesis, has been demonstrated in mammalian liver $(16)$, heart $(17,18)$, brain (19), and adipose tissue (20). In the human, fatty acid synthesis has been shown to occur by the malonylCoA pathway in adipose tissue (4) and possibly in liver (21).

The human erythrocyte contains a significant quantity of long chain fatty acids, largely in the form of complex structural lipids (22-24). Both

* Submitted for publication July 12, 1965; accepted October 18, 1965.

Supported by U. S. Public Health Service grants T1AM-5205-04-0481, AM-06852-02, and AM-04501-04.

A preliminary report has appeared (Clin. Res. 1965, 13, 280).

+ Address requests for reprints to Dr. Joseph G. Pittman, Massachusetts General Hospital, Boston, Mass. 02114. immature mammalian and nucleated avian erythrocytes have been shown to possess the ability to synthesize long chain fatty acids from acetate, but this ability is apparently lost in the mature mammalian red cell (25-28).

The present study was undertaken to extend the information available on the mechanism of fatty acid synthesis in this readily accessible tissue and to define the metabolic lesion responsible for the reported inability of these cells to synthesize long chain fatty acids.

\section{Methods}

Preparation of substrate. The following substrates, cofactors, and enzymes were purchased commercially: ATP,1 TPN,1 TPNH,1 DPNH,1 glucose-6-phosphate dehydrogenase, ${ }^{1}$ coenzyme $A,{ }^{2}$ acetic acid-1 ${ }^{14} \mathrm{C}$-anhydride, ${ }^{8}$ bicarbonate- ${ }^{11} \mathrm{C},{ }^{3}$ and malonic acid-2- ${ }^{14} \mathrm{C} .{ }^{3}$ Acetyl-CoA and acetyl-1- ${ }^{14} \mathrm{C}-\mathrm{CoA}$ were synthesized by the method of Simon and Shemin (29) and malonyl-CoA and malonyl2-14C-CoA by the method of Trams and Brady (30).

Preparation of enzymes. Hemolysates were prepared from heparinized blood from normal, nonfasting, adult volunteers without regard to diet. All operations were carried out at 0 to $4^{\circ} \mathrm{C}$. The erythrocytes were sepa-

TABLE I

Pathway of fatty acid biosynthesis

\begin{tabular}{lll}
\hline \hline Enzymes & Pathway & $\begin{array}{c}\text { Additional substrates } \\
\text { and cofactors }\end{array}$ \\
Acetyl-CoA synthetase & Acetate & ATP, $\mathrm{Mg}^{++}, \mathrm{CoASH}$ \\
Acetyl-CoA carboxylase & ATP, CO, $\mathrm{Mn}^{++}$
\end{tabular}

1 Sigma Chemical Co., St. Louis, Mo.

2 Pabst Laboratories, Milwaukee, Wis.

3 New England Nuclear Corp., Boston, Mass. 
rated by the dextran flotation technique (31). The supernatant was removed by aspiration and discarded. The erythrocytes were washed three times with cold isotonic saline (the final preparation contained always less than 1 leukocyte per 10,000 cells and often less than 1 per 100,000 cells). Hemolysis was accomplished by the addition of 2 parts of cold distilled water after which the hemolysate was buffered to 0.1 mole per $\mathrm{L}$ with an appropriate buffer (see below) and made 0.01 mole per $\mathrm{L}$ with respect to 2-mercaptoethanol. The preparation was centrifuged, either at $31,000 \times g$ for 15 minutes, after which it was used, or at $105,000 \times g$ for 1 hour. The latter preparation, in the experiments so designated, was further purified by ammonium sulfate precipitation (at a saturation of $40 \%$ ) and 2-hour dialysis against $0.05 \mathrm{M}$ buffer and 0.01 M 2-mercaptoethanol. Enzymatic activity was expressed per milligram protein or milligram hemoglobin. Protein was measured by the method of Warburg and Christian (32). Hemoglobin was measured as cyanmethemoglobin (33).

Preparation of enzymes from liver and adipose tissue was carried out as previously described (2).

Enzyme assays. Acetyl-CoA carboxylase was assayed as previously described, both by fixation of bicarbonate${ }^{14} \mathrm{C}$ with acetyl-CoA to form malonyl- ${ }^{14} \mathrm{C}-\mathrm{CoA}$ and by the hexane-extracted radioactive long chain fatty acids synthesized from acetyl-1- ${ }^{14} \mathrm{C}-\mathrm{CoA}$ in the presence of ATP, $\mathrm{MnCl}_{2}, \mathrm{KHCO}_{3}$, and citrate $(2,3)$. The assay of palmitate synthetase has also been described elsewhere (2). For the carboxylase assays the hemolysates were buffered with either Tris- $\mathrm{HCl}$ or imidazole- $\mathrm{HCl}$, pH 7.0. For the assay of palmitate synthetase, either $\mathrm{KHPO}_{4}, \mathrm{pH} 6.5$, or imidazole- $\mathrm{HCl}, \mathrm{pH} 6.8$, was used as a buffer.

Preliminary identification of the radioactive products of the reaction as long chain fatty acids was carried out

TABLE II

Requirements of palmitate synthetase in human erythrocytes*

\begin{tabular}{lc}
\hline \multicolumn{1}{c}{ Component omitted } & $\begin{array}{c}\text { Radioac- } \\
\text { tivity in } \\
\text { fatty acids }\end{array}$ \\
\hline None & $c p m$ \\
Malonyl-CoA & 15,256 \\
Acetyl-CoA & 93 \\
TPNH & 547 \\
TPNH (plus DPNH) & 135 \\
TPNH (plus TPNH generator) & 6,407 \\
None (boiled enzyme) & 31,395 \\
\end{tabular}

* The complete system contained $100 \mu$ moles of potassium phosphate buffer $(\mathrm{pH} 6.5), 4 \mu$ moles of DPNH or TPNH (or $4 \mu$ moles of TPN, $4 \mu$ moles of glucose-6-phosphate, and 3 enzyme $U$ of glucose-6-phosphate dehydrogenase), $0.5 \mu$ moles of malonyl-CoA, $0.25 \mu$ mole of acetyl-1-14C-CoA (specific activity, $10 \mu \mathrm{c}$ per $\mu \mathrm{mole}$ ), and $0.4 \mathrm{ml}$ of enzyme (containing $84 \mathrm{mg}$ of hemoglobin). Malonyl-2-14 $\mathrm{C}$-CoA was used to test the acetyl-CoA requirement. Final volume was $2 \mathrm{ml}$. Incubation was carried out at $37^{\circ} \mathrm{C}$ for 90 minutes.
TABLE III

Fatty acid synthesis from acetyl-CoA in different tissues*

\begin{tabular}{|c|c|c|c|}
\hline & \multicolumn{3}{|c|}{ Malonyl-CoA } \\
\hline & Added & Omitted & $\begin{array}{c}\text { Omitted, and } \\
\text { acetyl-CoA } \\
\text { carboxylase } \\
\text { cofactors } \\
\text { added }\end{array}$ \\
\hline & \multicolumn{3}{|c|}{ 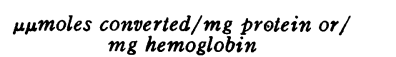 } \\
\hline Human erythrocytes & 5.12 & 0 & 0 \\
\hline Rat liver & 44.7 & 0.56 & 83.6 \\
\hline Rat adipose tissue & 119.0 & 0 & 434.0 \\
\hline
\end{tabular}

* Erythrocyte assays were carried out as in Table I. Rat liver and adipose tissue preparations were the supernatant solutions from $10,000 \times g$ centrifugations and contained 79 and $8.7 \mathrm{mg}$ of protein, respectively. The acetyl-CoA carboxylase cofactors included $40 \mu$ moles of $\mathrm{KHCO}_{3}, 6 \mu$ moles of ATP, $2 \mu$ moles of $\mathbf{M n C l}_{2}$, and $30 \mu$ moles of potassium citrate. The results shown are from a typical series of parallel experiments.

by saponification, followed by alkaline and acidic extractions with hexane, the acidic extract then being concentrated by evaporation and counted in a Packard liquid scintillation counter, as previously described (2). More precise definitions for the reaction products of the erythrocyte incubations were carried out, as noted below, by the use of thin layer and gas liquid chromatography.

Acetyl-CoA synthetase was assayed as described by Stacey, Latimer, and Tove (34). The incubation mixture contained $20 \mu$ moles of Tris- $\mathrm{HCl}$ buffer $(\mathrm{pH} 8.2)$, $2 \mu$ moles of ATP, $0.1 \mu$ mole of coenzyme A, $1 \mu$ mole of $\mathrm{MgCl}_{2}, 3 \mu$ moles of 2 -mercaptoethanol, $1 \mu$ mole of potassium fluoride, $0.1 \mu$ mole of sodium acetate- $1-{ }^{14} \mathrm{C}$ (specific activity, $20 \mu \mathrm{c}$ per $\mu$ mole), and from 0.01 to $0.10 \mathrm{ml}$ of hemolysate buffered with either Tris- $\mathrm{HCl}, \mathrm{pH} 8.2$, or imidazole- $\mathrm{HCl}, \mathrm{pH}$ 7.6. The final volume was $0.2 \mathrm{ml}$. The reaction was run at $37^{\circ} \mathrm{C}$ for 30 minutes and stopped by the addition of $0.05 \mathrm{ml}$ of $20 \%$ trichloroacetic acid. After brief centrifugation, $0.025 \mathrm{ml}$ of the reaction mixture was applied to a $1-\times 3-\mathrm{cm}$ strip of Whatman 1 filter paper, which was then steamed for 30 minutes, dried, and placed directly into a counting vial containing $10 \mathrm{ml}$ of phosphor ${ }^{4}$ and counted in a Packard liquid scintillation counter.

\section{Results}

Palmitate synthetase. Both hemolysates and partially purified enzyme preparations catalyzed the conversion of acetyl-1-14 $\mathrm{C}-\mathrm{CoA}$ or malonyl-2${ }^{14} \mathrm{C}-\mathrm{CoA}$ into hexane-extractable fatty acids ( Table II). The total palmitate synthetase activity that could be recovered from mature erythrocytes

4 The counting solution contained $4 \mathrm{~g}$ of 2,5-diphenyloxazole and $50 \mathrm{mg}$ of $p$-bis (5-phenyloxazoly1) 1-benzene per $L$ of toluene and was purchased from Pilot Chemicals, Waltham, Mass. 
was much less than that of mammalian liver or adipose tissue (Table III). However, since hemoglobin comprises about $98 \%$ of the total erythrocyte protein, the specific activity of this enzyme becomes comparable to these other tissues if related to the nonhemoglobin protein contained in the hemolysates. In 13 donors palmitate synthetase activity of stroma-free hemolysates ranged from 1.17 to $8.10 \mu \mu$ moles of acetyl-CoA converted to fatty acids per mg hemoglobin per 60 minutes. A satisfactory linear relationship between fatty acid synthesis and enzyme concentration was obtained (Figure 1). The ammonium sulfate precipitation step resulted in an approximately tenfold purification. Only feeble and inconsistent enzyme activity was present in the unwashed centrifuged stromal fraction. When stored at $4^{\circ} \mathrm{C}$ in $0.01 \mathrm{M}$ 2 -mercaptoethanol, about $50 \%$ of the original activity was lost in 5 days; without 2-mercaptoethanol, approximately $90 \%$ of the activity was gone in 48 hours.

The requirements for this enzyme are similar to those described for other mammalian systems (1-9). The results of a typical experiment are shown in Table II. Malonyl-CoA and TPNH were required absolutely. DPNH could partially fufill the requirement of a hydrogen donor. Whether DPNH was providing protons directly,

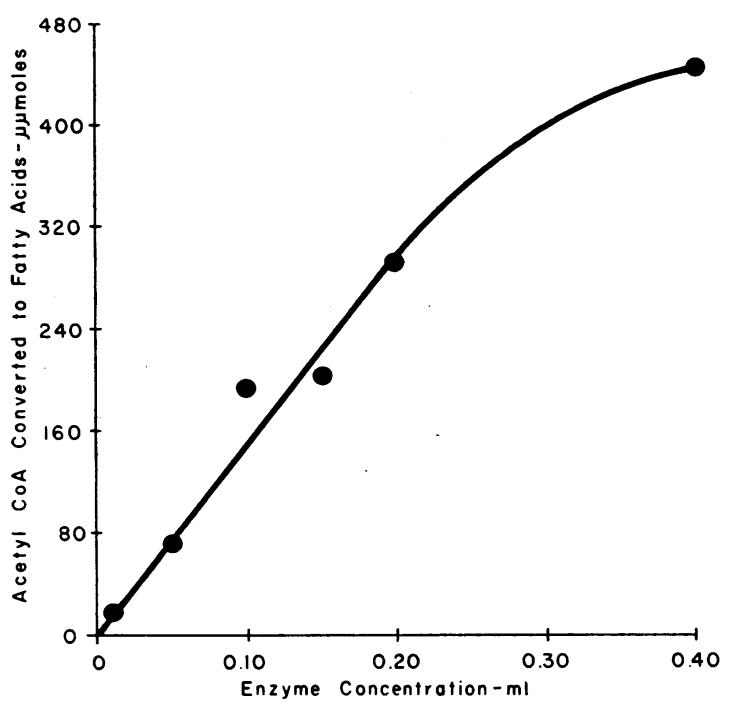

Fig. 1. ENzyme concentration CURve for palmitate SYNTHETASE IN HUMAN ERYTHROCYTES. The conditions of the assay are as described in Table I. The ammonium sulfate precipitated enzyme contained $159 \mathrm{mg}$ of hemoglobin per $\mathrm{ml}$.

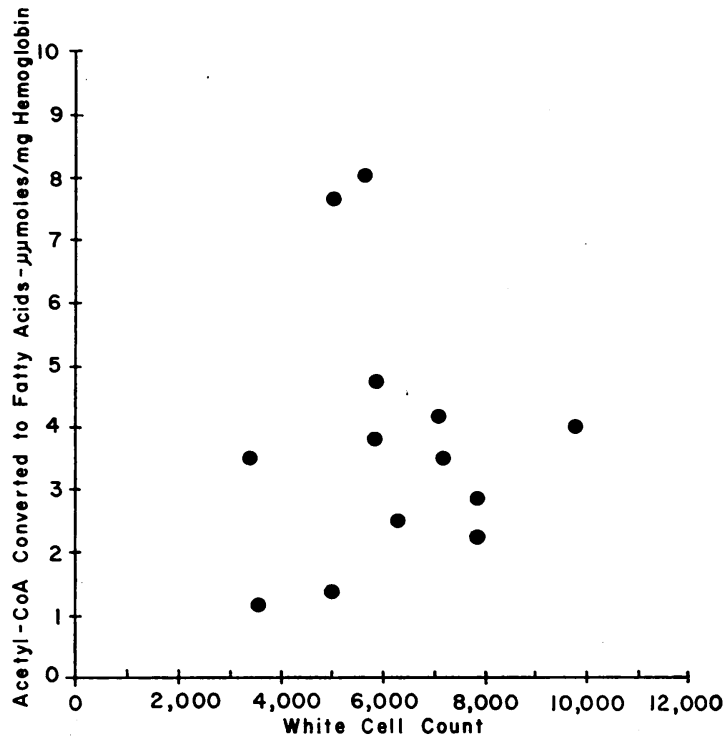

Fig. 2. LACK OF RELATIONSHIP BETWEen PALMitate SYNTHETASE ACTIVITY AND DONOR LEUKOCYTE COUNT. The stroma-free hemolysates were assayed as described in Table I. The correlation coefficient $(r=0.016)$ was not significant by Student's $t$ test. The mean (and standard error of the mean) for palmitate synthetase was $3.82 \pm 0.56 \mu \mu$ moles of acetyl-CoA converted to fatty acids per $\mathrm{mg}$ hemoglobin per 60 minutes.

or acting through a diaphorase to reduce TPN in these crude preparations, was not clear. Interestingly, a TPNH generating system usually proved more effective than TPNH (Table II). Nicotinamide, or DPNH, in addition to TPNH, had no significant additional effect. Omission of 2-mercaptoethanol from the incubation medium did not alter the amount of fatty acids synthesized but, as noted above, did influence the stability of the enzyme. The requirement for acetyl-CoA was present, but not absolute, due possibly to a contamination with the enzyme malonyl-CoA decarboxylase (that would yield acetyl CoA). The enzyme was inhibited by exposure to a sulfhydryl inhibitor [ $p$-hydroxymercuri-benzoate (PHMB) or iodoacetate] at a concentration of 0.2 mmole per $\mathrm{L}$, and the inhibition with PHMB could be reversed by the addition of 2-mercaptoethanol.

From 90 to $95 \%$ of the total radioactivity extracted into hexane could be recovered on thin layer chromatogram (silica gel G plates ${ }^{5}$; solvent system of $65 \%$ diethyl ether, $34 \%$ hexane, $1 \%$

\footnotetext{
s Brinkman Instruments, Great Neck, L. I., N. Y.
} 


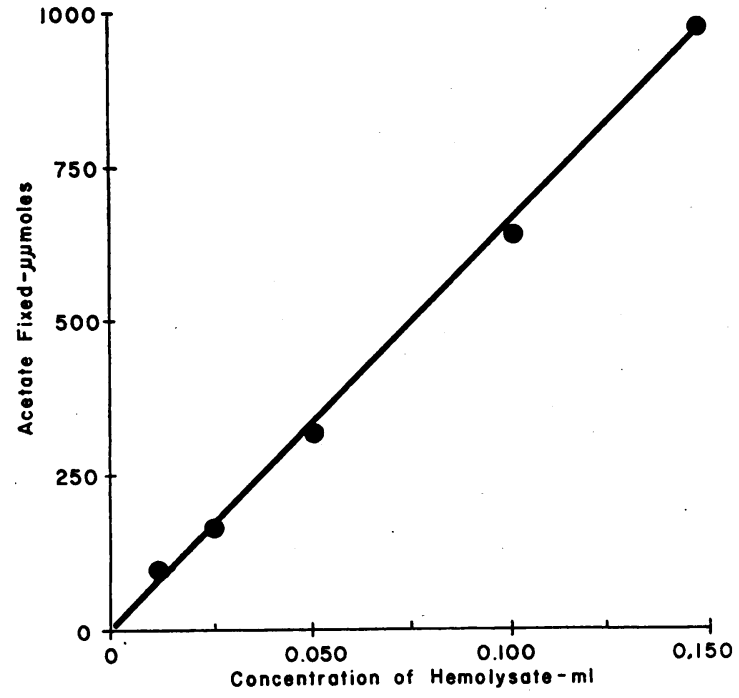

Fig. 3. ENZYME CONCENTRATION CURVE FOR ACETYLCOA SYNTHETASE IN HUMAN ERYTHROCYTES.

glacial acetic acid; running time, 40 minutes) in the area corresponding to $\mathrm{C} 12$ through $\mathrm{C} 18$ long chain fatty acids. Negligible radioactivity was found elsewhere on the chromatograms even when the nonsaponifiable lipid fraction was not removed by prior alkaline hexane extraction. Analysis by gas liquid chromatography revealed that $18 \%$ of the recovered radioactivity was in the $\mathrm{C} 14$ peak, $73 \%$ in the $\mathrm{C} 16$ peak, and $4 \%$ in the $\mathrm{C} 18$ peak ( $5 \%$ was found in an unidentified peak). ${ }^{\circ}$

The calculated ratio of malonyl-CoA to acetyl$\mathrm{CoA}$ incorporated into fatty acids was found to be 6.2 , suggesting that the stoichiometry of the reaction in this tissue is similar to other tissues studied $(2,6,11)$, that is, the condensation of 7 moles of malonyl-CoA with 1 mole of acetyl-CoA (and 14 moles of TPNH) to form palmitate.

The possibility was considered that leukocytes may have contributed to the fatty acid synthesis observed in these experiments. However, this seemed unlikely for several reasons: 1 ) there was no apparent relationship between the leukocyte count of the donor and the observed enzymatic activity (Figure 2 ) ; 2) contamination of the final washed erythrocyte suspension was minimal (see Methods) ; 3) human leukocytes showed consid-

6 Kindly done by Dr. J. Franks, Department of Medicine, Harvard Medical School, and Medical Services (Gastrointestinal Unit), Massachusetts General Hospital, Boston, Mass. erable resistance to lysis in distilled water, and it seems unlikely that many of the few remaining leukocytes were ruptured by the brief exposure to a hypotonic solution during preparation of the hemolysates; and 4) palmitate synthetase activity thus far has proven difficult to demonstrate in extracts of human leukocytes ruptured by ultrasonic vibration, pressure-homogenization, or agitation in $0.25 \mathrm{M}$ sucrose.

Acetyl-CoA carboxylase. This enzyme activity was absent, or virtually absent, by both methods of assay. No bicarbonate $-{ }^{14} \mathrm{C}$ fixation into malonyl-CoA occurred when hemolysates or partially purified enzyme preparations were assayed under conditions where acetyl-CoA carboxylase activity was easily demonstrable in rat liver and adipose tissue preparations. Furthermore, no acetyl-1${ }^{14} \mathrm{C}-\mathrm{CoA}$ was incorporated by erythrocyte preparations in the absence of added malonyl-CoA even when supplied with TPNH and the necessary cofactors and substrates for the carboxylase step (Table III). The possibility that very small amounts of malonyl-CoA were formed and then immediately decarboxylated by the enzyme malonylCoA decarboxylase cannot be rigorously excluded, but the amount of malonyl-CoA decarboxylase as assayed (Table II) is not great. The presence of an inhibitor of the carboxylase enzyme in mature erythrocytes was also considered. However, partially purified acetyl-CoA carboxylase from rat liver was not inhibited by hemolysates, rendering this possibility unlikely. The enzyme acetyl-CoA carboxylase would therefore appear to be absent, or virtually absent, from this tissue.

TABLE IV

Requirements for acetyl-CoA synthetase in human erythrocytes*

\begin{tabular}{lr}
\hline Component omitted & $\begin{array}{c}\text { Radioac- } \\
\text { tivity } \\
\text { fixed }\end{array}$ \\
\hline & $c p m$ \\
None & 2,996 \\
ATP & 62 \\
Coenzyme A & 80 \\
$\mathrm{MgCl}_{2}$ & 443 \\
$\mathrm{MgCl}_{2}$ (plus $\mathrm{MnCl}_{2}$ ) & 4,584 \\
$2-\mathrm{Mercaptoethanol}_{\mathrm{KF}}$ & 4,524 \\
$\mathrm{KF}$ & 1,558 \\
None (boiled enzyme) & 84 \\
\hline
\end{tabular}

* The complete system contained $0.1 \mathrm{ml}$ of hemolysate (7.5 mg of hemoglobin) with other additions as described in the text. An equimolar amount of $\mathrm{MgCl}_{2}$ was substituted for $\mathrm{MnCl}_{2}$. 
Acetyl-CoA synthetase. Both the crude and the stroma-free hemolysates were able to catalyze the fixation of radioactive acetate as acetyl-CoA. The acetyl-CoA synthetase activity of stroma-free hemolysates from 12 donors ranged from 45 to 286 $\mu \mu$ moles of acetate fixed per $\mathrm{mg}$ hemoglobin per 30 minutes. A satisfactory linear relationship was found between the amount of acetate fixed and the concentration of hemolysate (Figure 3 ). The requirements of the reaction were similar to those of other mammalian acetyl-CoA synthesizing enzyme systems (15-19), and the results of a typical experiment are shown in Table IV. The requirements for ATP and coenzyme A were absolute, and for a divalent cation nearly so (manganese and magnesium were interchangeable). The ATP requirement could not be replaced by uridine, cytidine, or guanidine triphosphates.

The addition of potassium fluoride enhanced, but was not essential for the reaction, and the omission of 2-mercaptoethanol had a similar effect (Table IV). Both ammonium and potassium ions were found to stimulate the reaction, whereas lithium, and less consistently sodium ions, caused inhibition of the reaction at similar concentrations $(0.01 \mathrm{M})$.

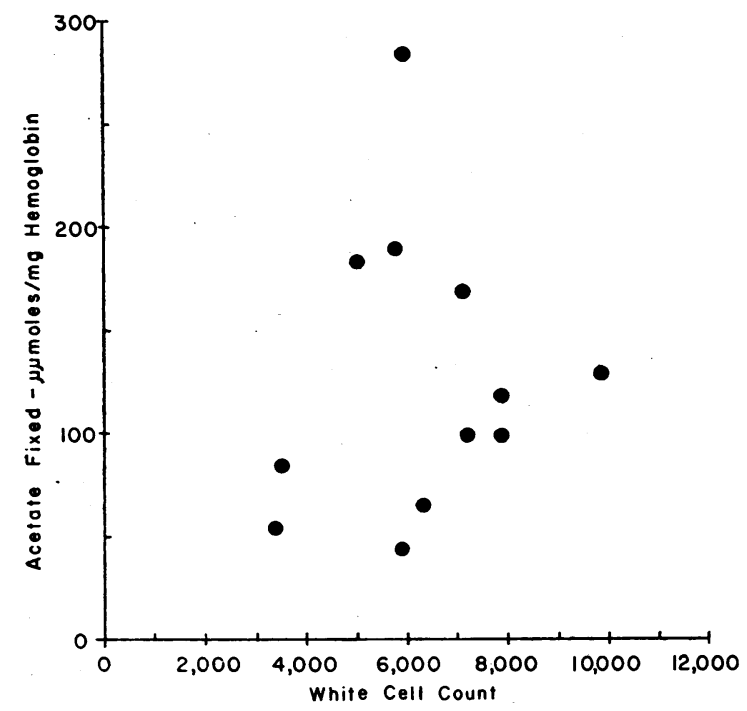

Fig. 4. LACR OF RELATIONSHIP BETWEEN ACETYL-CoA SYNTHETASE ACTIVITY AND DONOR LEUKOCYTE COUNT. The correlation coefficient $(r=0.13)$ was not significant by Student's $t$ test. The mean (and standard error of the mean) for acetyl-CoA synthetase was $128 \pm 19 \mu \mu$ moles of acetate fixed per $\mathrm{mg}$ hemoglobin per 30 minutes.

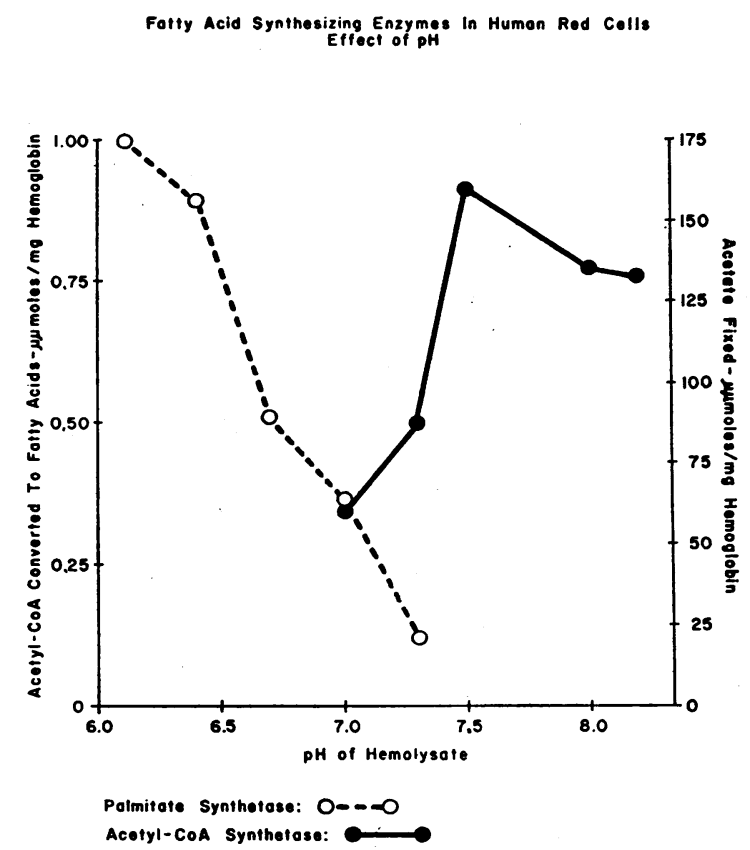

Fig. 5. EFFect OP PH ON ACETYL-COA SYNTHETASE (O-O) AND PALMTATE SYNTHETASE (O---OO) ACTIVITY.

Acetate was the only short chain fatty acid catalyzed by this enzyme system. Small amounts of propionate-1-14 $\mathrm{C}$, but no butyrate- $1-{ }^{14} \mathrm{C}$, hexanoate-1-14 $\mathrm{C}$, or octanoate- $1-{ }^{14} \mathrm{C}$ were fixed.

A significant contribution by contaminating leukocytes to the activity of this enzyme seems unlikely for the same reasons as described above for palmitate synthetase. There was no correlation between the leukocyte count of the donor and the acetyl-CoA synthetase activity found in the washed erythrocyte hemolysate (Figure 4).

Acetate-1-14C incorporation into fatty acids. The demonstration of both acetyl-CoA synthetase and palmitate synthetase suggested that the overall synthesis of fatty acids from acetate could be accomplished if the deficient acetyl-CoA carboxylase step were bypassed by the addition of malonylCoA. However, initial attempts to show this conversion were unsuccessful until the large difference in $\mathrm{pH}$ optima for the two reactions was appreciated (Figure 5). As described in Table V, the experiment was carried out in two stages: first the incubation media were buffered at $\mathrm{pH} 8.2$ to allow maximal acetyl-CoA synthetase activity, after which the $\mathrm{pH}$ was lowered, and the cofactors and substrates were added for the second reaction, 
TABLE V

Incorporation of acetate into fatty acids*

\begin{tabular}{lc}
\hline \hline Component omitted & $\begin{array}{c}\text { Radioac- } \\
\text { tivity in } \\
\text { fatty acids }\end{array}$ \\
\hline None & $c p m$ \\
ATP & 3,680 \\
Coenzyme A & 21 \\
MgCl $_{2}$ & 206 \\
Malonyl-CoA & 451 \\
& 11 \\
\hline
\end{tabular}

* The incubation was carried out in two stages. The first part was carried out with $0.1 \mathrm{ml}$ of hemolysate (containing $10 \mathrm{mg}$ of hemoglobin) at $37^{\circ} \mathrm{C}$ for 45 minutes under conditions as described in the text for the acetyl-CoA synthetase assay. The second part contained $25 \mu$ moles of potassium phosphate buffer ( $\mathrm{pH} 5.5$ ), $0.6 \mu$ mole of malonyl-CoA, $10 \mu$ moles of glucose-6-phosphate, $2 \mu$ moles of TPN, 3 enzyme U of glucose-6-phosphate dehydrogenase, $2.5 \mu$ moles of 2 -mercaptoethanol, and $0.3 \mathrm{ml}$ of partially purified (erythrocyte) palmitate synthetase. The final volume was $0.88 \mathrm{ml}$. The second incubation was stopped after 60 minutes.

palmitate synthetase. Under these conditions the incorporation of acetate into fatty acids could be repeatedly demonstrated. Here again, despite the addition of acetyl-CoA carboxylase cofactors, the requirement for malonyl-CoA was virtually absolute. These experiments also gave added validity to the assumption that a major part of the radioactive acetate fixed was as acetyl-1-14 $\mathrm{C}-\mathrm{CoA}$.

\section{Discussion}

The results of the present investigation indicate a close similarity between the fatty acid synthesizing system of human red cells and other mammalian tissues. All are in the particle-free ("soluble") portion of the cell, apparently synthesize long chain fatty acids with malonyl-CoA as the key intermediate, have similar substrate and cofactor requirements, have the same stoichiometry, and are inhibited by sulfhydryl inhibitors. That red cells should employ this pathway is not surprising in view of the similar mesenchymal origins of the hemic and a number of other fatty acid synthesizing mammalian tissues, notably adipose tissue. The studies of Wasserman suggest that with an adequate stimulus, adipose tissue in certain regions of the body may exert hematopoietic activity, and, conversely, certain hematopoietic tissues may be transformed into fat cells and resume the function of lipid synthesis and storage (35).

The finding of palmitate synthetase in mature erythrocyte extracts provides inferential evidence that fatty acid synthesis occurs by the malonylCoA pathway in younger precursors of the red cell series. A deficiency of acetyl-CoA carboxylase would explain the reported inability of the mature cell to synthesize fatty acids from acetate $(25,26,28)$. The possibility that malonyl-CoA decarboxylase was decarboxylating the malonyl$\mathrm{CoA}$ (to form acetyl-CoA) as fast as it was synthesized seems unlikely because of the relatively small amounts of this enzyme demonstrable.

Several investigators have reported that mature human erythrocytes retain the ability to carry out de novo synthesis of fatty acids and other lipids from acetate or glucose $(36-41)$. Such conclusions are at variance with our study and those of other workers $(25,26,28)$, some of whom have suggested that these systems may have been contaminated with leukocytes and platelets. The mature human erythrocyte, although incapable of $d e$ novo fatty acid biosynthesis, apparently retains the ability to incorporate preformed fatty acids into membrane lipids $(42,43)$.

The site of the block in fatty acid biosynthesis described in this study reinforces the pivotal role of the enzyme acetyl-CoA carboxylase in the regulation of fatty acid biosynthesis. This enzyme is apparently rate limiting in adipose tissue and liver $(2,3,7)$. In addition, alterations in fatty acid synthesis can be ascribed to parallel changes in carboxylase activity in a number of situations: 1) the stimulation by tricarboxylic acid cycle intermediates, most notably citrate and isocitrate (44 $46)$; 2) the stimulation by preincubation with mitochondria $(47)$; 3) the diminution in enzymatic activity secondary to starvation, fat feeding, and diabetes mellitus $(7,48-50)$; and 4$)$ the inhibition by coenzyme A esters of long chain fatty acids (51).

The results of the present study are therefore in keeping with the growing body of evidence implicating the level of acetyl-CoA carboxylase activity as playing a critical role in the control of fatty acid biosynthesis.

\section{Summary}

Long chain fatty acid synthesis from acetate has been studied in cell-free preparations of human erythrocytes. The pathway seems to be the same as in other mammalian systems studied and uses malonyl-coenzyme $\mathrm{A}$ as a key intermediate. En- 
zyme systems with the characteristics of palmitate synthetase and acetyl-coenzyme A synthetase were identified; their properties were similar to those of other mammalian tissues. However, no acetylcoenzyme A carboxylase activity was demonstrable, which would explain the reported inability of mature erythrocytes to synthesize long chain fatty acids from acetate. This finding also supports the concept that this enzyme plays a pivotal role in the regulation of fatty acid biosynthesis.

The results of this study would indicate that fatty acid biosynthesis occurs by the so-called malonyl-coenzyme A pathway at an early stage of red cell development, and that the loss of this synthetic activity may be due to the loss during maturation of the entyme acetyl-CoA carboxylase.

\section{References}

1. Larrabee, A. R., E. G. McDaniel, H. A. Bakerman, and P. R. Vagelos. Acyl carrier protein. V. Identification of $4^{\prime}$-phosphopantetheine bound to a mammalian fatty acid synthetase preparation. Proc. nat. Acad. Sci. (Wash.) 1965, 54, 267.

2. Martin, D. B., M. G. Horning, and P. R. Vagelos. Fatty acid synthesis in adipose tissue. I. Purification and properties of a long chain fatty acidsynthesizing system. J. biol. Chem. 1961, 236, 663.

3. Ganguly, J. Studies on the mechanism of fatty acid synthesis. VII. Biosynthesis of fatty acids from malonyl CoA. Biochim. biophys. Acta (Amst.) 1960, 40, 110.

4. Jacob, M. I. Fatty acid synthesis in cell-free preparations of human adipose tissue. Biochim. biophys. Acta (Amst.) 1963, 70, 231.

5. Brady, R. O., and S. Gurin. Biosynthesis of fatty acids by cell-free or water-soluble enzyme systems. J. biol. Chem. 1952, 199, 421.

6. Wakil, S. J. Mechanism of fatty acid synthesis. J. Lipid Res. 1961, $2,1$.

7. Numa, S., M. Matsuhashi, and F. Lynen. Zur Störungder Fettsäuresynthese bei Hunger und Alloxan-Diabetes. I. Fettsäuresynthese in der Leber normaler und hungernder Ratten. Biochem. Z. 1961, 334, 203.

8. Popják, G., and A. Tietz. Biosynthesis of fatty acids in cell-free preparations. II. Synthesis of fatty acids from acetate by a soluble enzyme system prepared from rat mammary gland. Biochem. J. 1955, $60,147$.

9. Hele, P., G. Popják, and M. Lauryssens. Biosynthesis of fatty acids in a cell-free preparation from acetate by a partially purified enzyme system from rat mammary gland. 4. Synthesis of fatty acids. Biochem. J. 1957, 65, 348.
10. Brady, R. O. Biosynthesis of fatty acids. II. Studies with enzymes obtained from brain. J. biol. Chem. 1960, 235, 3099.

11. Lynen, F. Biosynthesis of saturated fatty acids. Fed. Proc. 1961, 20, 941.

12. Stumpf, P., and A. T. James. The biosynthesis of long-chain fatty acids by lettuce chloroplast preparations. Biochim. biophys. Acta (Amst.) 1963, 70, 20.

13. Tietz, A. Fat synthesis in cell-free preparations of the locust fat-body. J. Lipid Res. 1961, 2, 182.

14. Zebe, E. C., and W. H. McShan. Incorporation of $\left[{ }^{14} \mathrm{C}\right]$ acetate into long chain fatty acids by the fat body of Prodenia eridania (Lep.). Biochim. biophys. Acta (Amst.) 1959, 31, 513.

15. Goldman, P., A. W. Alberts, and P. R. Vagelos. The condensation reaction of fatty acid biosynthesis. II. Requirement of the enzymes of the condensation reaction for fatty acid synthesis. J. biol. Chem. 1963, 238, 1255.

16. Kornacker, M. S., and J. M. Lowenstein. Citrate cleavage and acetate activation in livers of normal and diabetic rats. Biochim. biophys. Acta (Amst.) 1964, 84, 490.

17. Hele, $P$. The acetate activating enzyme of beef heart. J. biol. Chem. 1954, 206, 671.

18. Campagnari, F., and L. T. Webster, Jr. Purification and properties of acetyl coenzyme $A$ synthetase from bovine heart mitochondria. J. biol. Chem. 1963, 238, 1628.

19. Schuberth, J. On the biosynthesis of acetyl coenzyme $A$ in the brain. I. The enzymic formation of acetyl coenzyme A from acetate, adenosine triphosphate and coenzyme A. Biochim. biophys. Acta (Amst.) 1965, 98, 1.

20. Martin, D. B., and J. G. Pittman. Unpublished observations.

21. Bortz, W., S. Abraham, I. L. Chaikoff, and W. E. Dozier. Fatty acid synthesis from acetate by human liver homogenate fractions. J. clin. Invest. $1962,41,860$.

22. Munn, J. I. Studies on lipids in human red cells. Brit. J. Haemat. 1958, 4, 344.

23. Prankerd, T. A. J. The Red Cell: An Account of Its Chemical Physiology and Pathology. Oxford, Blackwell, 1961, p. 16.

24. Ways, P., and D. J. Hanahan. Characterization and quantification of red cell lipids in normal man. J. Lipid Res. 1964, 5, 318.

25. Marks, P. A., A. Gellhorn, and C. Kidson. Lipid synthesis in human leukocytes, platelets, and erythrocytes. J. biol. Chem. 1960, 235, 2579.

26. O’Donnell, V. J., P. Ottolenghi, A. Malkin, O. F. Denstedt, and R. D. H. Heard. The biosynthesis from acetate-1- $\mathrm{C}^{14}$ of fatty acids and cholesterol in formed blood elements. Canad. J. Biochem. 1958, $36,1125$.

27. Webb, J. P. W., A. C. Allison, and A. T. James. In vitro lipid synthesis in fowl blood. Biochim. biophys. Acta (Amst.) 1960, 43, 89. 
28. Buchanan, A. A. Lipid synthesis by human leukocytes in vitro. Biochem. J. 1960, 75, 315.

29. Simon, E. J., and D. Shemin. The preparation of s-succinyl coenzyme A. J. Amer. chem. Soc. 1953, 75, 2520.

30. Trams, E. G., and R. O. Brady. The synthesis of malonyl-C14 coenzyme A. J. Amer. chem. Soc. 1960, 82, 2972.

31. Skoog, W. A., and W. S. Beck. Studies on the fibrinogen, dextran and phytohemagglutinin methods of isolating leukocytes. Blood 1956, 11, 436.

32. Warburg, O., and W. Christian. Isolierund und Kristallisation des Gärungsferments Enolase. Biochem. Z. 1941-43, 310, 384.

33. Page, L. B., and P. J. Culver, Eds. A Syllabus of Laboratory Examinations in Clinical Diagnosis. Cambridge, Harvard University Press, 1961.

34. Stacey, R. E., S. B. Latimer, and S. B. Tove. Determination of acyl-CoA synthetase activity for volatile fatty acids. Biochim. biophys. Acta (Amst.) 1964, 84, 192.

35. Wasserman, F. The concept of the "fat organ" in Fat as a Tissue, K. Rodahl and B. Issekutz, Jr., Eds. New York, McGraw-Hill, 1964, p. 22.

36. Altman, K. I., and S. N. Swisher. Incorporation of acetate-2-14C into human erythrocyte stroma as a function of storage. Nature (Lond.) 1954, 174, 459.

37. James, A. T., J. E. Lovelock, and J. P. W. Webb. The lipids of whole blood. I. Lipid biosynthesis in human blood in vitro. Biochem. J. 1959, 73, 106.

38. Rowe, C. E., A. C. Allison, and J. E. Lovelock. Synthesis of lipids by different human blood cell types. Biochim. biophys. Acta (Amst.) 1960, 41, 310.

39. Mendelsohn, D. The metabolism of the human red blood cell. I. Interrelationships of carbohydrate and lipid metabolism in the human erythrocyte in vivo. A comparison between diabetic patients and normal subjects. S. Afr. J. med. Sci. 1961, 26, 15.

40. Mendelsohn, D. The metabolism of the human red blood cell. II. Interrelationships of carbohydrate and lipid metabolism of the human erythrocyte in vitro. A comparison between diabetic patients and normal subjects. S. Afr. J. med. Sci. 1961, 26, 24.

41. Charlton, R. W., and D. Mendelsohn. Certain aspects of carbohydrate and lipid metabolism in primaquine sensitive erythrocytes. S. Afr. J. med. Sci. 1961, 26, 109.

42. Mulder, E., J. De Gier, and L. L. M. Van Deenen. Selective incorporation of fatty acids into phospholipids of mature red cells. Biochim. biophys. Acta (Amst.) 1963, 70, 94.

43. Oliveira, M. M., and M. Vaughan. Incorporation of fatty acids into phospholipids of erythrocyte membranes. J. Lipid Res. 1964, 5, 156.

44. Martin, D. B., and P. R. Vagelos. The mechanism of tricarboxylic acid cycle regulation of fatty acid synthesis. J. biol. Chem. 1962, 237, 1787.

45. Waite, M., and S. J. Wakil. Studies on the mechanism of fatty acid synthesis. XII. Acetyl CoA carboxylase. J. biol. Chem. 1962, 237, 2750.

46. Kallen, R. G., and J. M. Lowenstein. The stimulation of fatty acid synthesis by isocitrate and malonate. Arch. Biochem. 1962, 96, 188.

47. Martin, D. B., and J. G. Pittman. Stimulation of fatty acid biosynthesis by rat liver mitochondria. Clin. Res. 1965, 13, 328.

48. Gibson, D. M., and D. D. Hubbard. Incorporation of malonyl CoA into fatty acids by liver in starvation and alloxan-diabetes. Biochem. biophys. Res. Commun. 1960, 3, 531.

49. Korchak, H. M., and E: J. Masoro. Changes in the level of fatty acid synthesizing enzymes during starvation. Biochim. biophys. Acta (Amst.) 1962, 58, 354.

50. Bortz, W., S. Abraham, and I. L. Chaikoff. Localization of the block in lipogenesis resulting from feeding fat. J. biol. Chem., 1963, 238, 1266.

51. Bortz, W. M., and F. Lynen. The inhibition of acetyl CoA carboxylase by long chain acyl CoA derivatives. Biochem. Z. 1963, 337, 505.

\section{SPECIAL NOTICE TO SUBSCRIBERS}

Post Offices will no longer forward the Journal when you move.

Please notify The Journal of Clinical Investigation, Business Office, 10 Stoughton Street, Boston, Mass. 02118, at once when you have a change of address, and do not omit the Zip Code number. 